\title{
"SEM AS PLANTAS A RELIGIÃO NÃO EXISTIRIA": SIMBOLOGIA E VIRTUALIDADE DAS PLANTAS NAS PRÁTICAS DE CURA EM COMUNIDADES TRADICIONAIS DE TERREIROS AMAZÔNICOS (SANTARÉM, PA) ${ }^{1}$
}

\author{
Myrian Sá Leitão Barboza² \\ Carla Ramos Munzanzu ${ }^{3}$ \\ Izonara Augusta dos Santos Souza ${ }^{4}$ \\ Edivanei de Oyá $a^{5}$
}

\begin{abstract}
RESUMO
Existe uma estreita e intensa conexão entre as plantas e as comunidades de Terreiros de religiões de matriz africana, permeada por um complexo estrutural e simbólico de crenças. O emprego das plantas nas práticas de cura nas religiões de matriz africana abrange um universo de mistérios e segredos, que inclui amplo conhecimento e cuidados específicos na coleta, preparo e uso dos vegetais. Fundamentados no sistema nativo de classificação e saberes tradicionais, realizamos um estudo exploratório sobre a simbologia e ritualística que envolve os Bàbálósányìn e as Iyálósányìn (responsáveis por colher as plantas e prepará-las para os rituais), e a prática de prescrição e aplicação de plantas nos processos terapêuticos de duas comunidades de religiões de matriz africana de Santarém (PA), na Amazônia.
\end{abstract}

Palavras-chaves: Plantas. Saúde. Cura. Religiões de matriz africana.

\section{"WITHOUT PLANTS THE RELIGION DID NO EXIST" : SYMBOLOGY AND VIRTUALITY OF OF PLANTS IN THE CURE PRACTICES OF AFRO-BRAZILIAN RELIGION IN AMAZON (SANTARÉM, PA)}

\begin{abstract}
There exists a close and in-depth connection between the plants and the Terreiros, places of AfroBrazilian religion, which are permeated by a complex structural and symbolic belief. The use of plants in the health treatment practice of Afro-Brazilian religion embraces a universe of mystery and secret, besides specific knowledge during the collection, preparation and use of plants. Based on the native system of classification and the traditional knowledge, we propose an exploratory study on the ritualistic developed by the Bàbálósányìn and Iyálósányìn (responsible for the plants) and the symbology of plants used in the therapeutic processes of two Afro-Brazilian Terreiros in Santarém, Brazil.
\end{abstract}

Key-words: Plants. Health. Cure. African Matrix Religions.

Data de submissão: 20.04 .2021

Data de aprovação: 20.06 .2021

\footnotetext{
${ }^{1}$ A versão preliminar deste texto foi apresentada na $29^{a}$ Reunião Brasileira de Antropologia em 2014, em NatalRN. Este estudo fez parte subprojeto "Etnoecologia das casas/terreiros de religiões de matriz Afro e/ou Ameríndia na cidade de Santarém/Pará”, coordenado por Myrian Sá Leitão Barboza, inserido no projeto de extensão (PROEXT MEC 2012/UFOPA) "Mapeamento das casas/terreiros de religiões de matriz afro e/ou ameríndia na cidade de Santarém/Pará", coordenado por Carla Ramos Munzanzu.

${ }^{2}$ Bióloga com doutorado em Antropologia e Estudos Latino-Americanos (University of Florida), professora do Programa de Antropologia e Arqueologia (PAA), Universidade Federal do Oeste do Pará (UFOPA) e vicecoordenadora do NPDAFRO, myrianbarboza@ufl.edu.

${ }^{3}$ Doutora em Estudos Africanos e Diáspora Africana, e Estudos em Gênero e Mulheres (University of Texas), professora do curso de Antropologia (PAA/UFOPA), coordenadora do Núcleo de Pesquisa e Documentação das Expressões Afro-Religiosas no Oeste do Pará e Caribe (NPDAFRO), E-mail: carlaramos@utexas.edu.

${ }^{4}$ Bióloga, Hunsó Omifele do Templo Religioso de Matriz Africana Kwe Oto Sindoya, izonarsouza23@gmail.com

5 Bàbálórìsá do Terreiro de Mina Santa Bárbara.
} 


\section{INTRODUÇÃO}

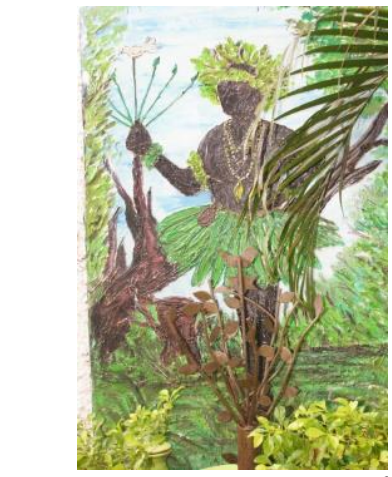

Kôsi ewe, kôsí Orixá ${ }^{6}$

("Sem folha não há Orixá”)

Nas religiões de matriz africana as plantas apresentam valor inestimável entre suas lideranças, zeladoras e praticantes, sendo extremamente valorizadas e respeitadas, pois compreendem um legado de conhecimentos que fundamentam a essência e a sobrevivência das próprias comunidades e seus sistemas filosóficos. Assim, inspiradas na virtualidade e autoridade das plantas para as comunidades afro-religiosas, abrimos nosso texto com uma formulação importante para a cosmologia das comunidades tradicionais de Terreiro no Brasil, a de que "sem as plantas, a religião não existiria"7.

$\mathrm{O}$ uso das plantas nas comunidades afro-religiosas constitui-se como prática indispensável não apenas para a realização dos rituais, celebrações de festas, como também no repertório que envolve cuidados do corpo e da alma (AZEVEDO, 2014). Para Lody (2006: 257) "são fortes os vínculos das folhas de defesa com a história fitolátrica e tradicional dos Terreiros". No sistema de crenças nas religiões de matriz africana, os vegetais possuem importante papel, representando a função de mediadoras entre dois planos de existência: o mundo dos vivos e das representações físicas; e o mundo sobrenatural (ALBUQUERQUE E ANDRADE, 2005).

De maneira geral, é bastante frequente a busca pela promoção de saúde através das consultas terapêuticas e religiosas com uso de vegetais nas comunidades de matriz africana em Santarém. Em estudo realizado em Terreiros de umbanda de São Paulo, Concone (2008) verificou que a maioria dos frequentadores recorre a estes espaços religiosos em busca de superação de sofrimento e aflição relacionados a questões de saúde. A pesquisadora tentou compreender os prováveis motivos para a procura destes espaços pela população envolvida que apresentava facilidade de acesso à medicina convencional - e constatou que esta busca ocorria concomitantemente aos tratamentos médicos científicos, e não uma substituição ou alternância. Na Amazônia, pesquisadores também verificaram as consultas sincrônicas à medicina convencional bem como aos tratamentos de cura religiosos em comunidades de Terreiros do Marajó (PA) e no Amapá (ALMEIDA, 2019; CORDEIRO, 2016; PACHECO, 2013).

Souza Junior, 2011, p.76-77, Bàbálórisá ${ }^{8}$ do Ilê Obá L’Okê, professor e doutor em antropologia na Bahia, alega que "o tratamento mágico-religioso não dispensa o outro tratamento, e nem muito menos o saber médico desautoriza nem concorre com as diferentes

\footnotetext{
${ }^{6}$ Imagem de Òsányìn (Ossaim) presente no Terreiro Kwe Oto Sindoya (Santarém-Pará), e logo abaixo uma expressão em nagô extraída de Lima (2010, p.50).

${ }^{7}$ Essa ideia tem sido contada e cantada para nós, pesquisadoras, em grande parte das entrevistas que costumamos realizar junto às lideranças religiosas de Terreiro. No Terreiro de Sindoya (Kwe Oto Sindoya), o Ògá Paulo, nos contou sobre essa mesma concepção basilar para as comunidades.

${ }^{8}$ Sacerdote de Candomblé, autoridade máxima na hierarquia do Terreiro.
} 
maneiras de restabelecer o equilíbrio utilizado pelas comunidades-terreiros". Todavia, Souza Junior adverte a perspectiva materialista, fragmentada e não-humanista da medicina tradicional que compreende o corpo de maneira desmembrada e distanciada.

O sacerdote juremeiro, candomblecista, historiador e mestre em ciências da religião, Alexandre L'Omi L'Odo, alerta que por causa da falha do estado brasileiro em ações adequadas de políticas públicas de acesso e direito à saúde, as comunidades de baixa renda no Nordeste costumam recorrer aos Terreiros de matriz africana em busca de tratamentos de cura para doenças físicas e psicológicas (L'OMI L'ODO, 2021). Assim, para o sacerdote, os Terreiros de Jurema e Candomblé funcionam como verdadeiros e importantes "hospitais dos pobres", mas que possuem relevante papel para a sociedade mais rica que também busca terapias de cura nestes espaços ${ }^{9}$. Para L'Omi L'Odo, as comunidades de Terreiros vêm perpetuando ações históricas de cuidado corporal, espiritual e mental por meio do uso sagrado das plantas. A religião se nutre e se fortalece por meio da força dos elementos da natureza, como a força de uma semente, de uma folha, de um fruto, de uma raiz, de uma casca, de uma árvore, de uma madeira, de uma erva, enfim, a religião utiliza a força potencializadora e curadora dos vegetais nos procedimentos terapêuticos.

\begin{abstract}
Assim a saúde está diretamente ligada à relação que o indivíduo possui com a sua ancestralidade. Ter saúde é ter axé, este princípio que nos faz correr, andar, conversar, ter sucesso, sermos dinâmicos e nos manter vivos no mundo. Assim, no Universo tudo é uma troca de axé. É o axé que dá sentido às coisas. Sendo o corpo uma miniatura do universo, é sobre ele que recaem os sinais de desequilíbrio (SOUZA JUNIOR, 2011. p. 76).
\end{abstract}

Inúmeros estudos etnobotânicos vêm demonstrando que as comunidades afro-religiosas fazem intenso uso de uma impressionante variedade de plantas, contribuindo, desta maneira, para a formação de um rico e detalhado complexo fitocultural brasileiro (GOMES et al, 2008; PIRES et al, 2009; SATIRO et al, 2019). Em dez Terreiros pesquisados de Ilhéus e Itabuna (BA), Pires e colaboradores (2009) identificaram 78 espécies de uso medicinal; nos cinco Terreiros de umbanda e candomblé investigados em Campina Grande (PB), Gomes e colaboradores (2008) identificaram o uso de 101 espécies vegetais; no agreste de Alagoas, Sátiro et al (2019) identificaram 198 espécies de uso místico, mágico e medicinal, utilizadas entre 30 Terreiros de candomblé.

Considerando o papel fundamental das plantas nas comunidades afro-religiosas, o presente texto tem como objetivo apresentar um estudo preliminar da simbologia das mesmas, através de levantamento dos diferentes usos e do seu papel para as comunidades de religiões de matriz africanas na cidade de Santarém, além das relações que envolvem os mediadores e frequentadores destes espaços. Relações estas que perpassam o ato de "medicar", constituindo as ações de coleta, cantos, preparo, cultivo e manutenção das plantas. Adicionalmente, apresentamos as atividades dos zeladores responsáveis pelos cuidados e manuseio com as plantas, e as entidades responsáveis pelas plantas e promoção da saúde.

\footnotetext{
${ }^{9}$ É preciso ressaltar que essa é uma leitura particular a respeito dos "motivos", que levariam as pessoas a buscarem cuidados para sua saúde junto às comunidades tradicionais de Terreiro. Há um rico debate que aponta para outras dimensões sócio históricas desse mesmo fenômeno. O debate feito por Glória Wekker (2006), tomando a realidade das mulheres negras de classe trabalhadora surinamesa, mostra a dinâmica histórica da presença das religiões de matriz africana no cotidiano das populações de uma maneira intrínseca e complexa. Esses acervos, digamos assim, (espiritual) afro-surinameses, informam diretamente os modos como as pessoas vivem os seus dilemas, e o modo como tomam as suas decisões no dia-a-dia. Essa perspectiva escapa a uma lógica de explicação que se baseia num quadro sociológico em que a "falta" de acesso ao sistema normativo de cuidado com a saúde é substituído por "alternativas" mais precárias.
} 
Em meados de 2011 iniciamos um projeto que mapeou um grupo de Terreiros de nação Ketu, Mina, Umbanda e Jeje Savalu na cidade de Santarém ${ }^{10}$. Além das atividades de pesquisa, o projeto de mapeamento articulou dezenas de ações de extensão junto às comunidades tradicionais de Terreiro ao longo de quase dez anos. Uma de nossas frentes de trabalho envolveu a produção de algumas etnografias no Terreiro de Mina Santa Bárbara, nação Mina, e no Terreiro Kwe Oto Sindoya, de tradição Jeje Savalu.

Nestas comunidades realizamos um levantamento etnobotânico e etnografias curtas, dando ênfase ao trabalho dos zeladores responsáveis pela coleta, preparo e aplicação das plantas. Ao longo dos três anos iniciais do projeto (2011-2013) participamos de inúmeras cerimônias e rituais, públicos e privados, realizados pelas comunidades tradicionais de Terreiro da cidade de Santarém, com olhar atento para o manuseio e emprego das plantas durante as cerimônias ${ }^{11}$.

\section{CARACTERIZAÇÃO DAS COMUNIDADES DE TERREIROS VISITADAS}

\subsection{TERREIRO DE MINA SANTA BÁRBARA}

Pai Edivanei de Oyá é a liderança religiosa e fundador do Terreiro, que data dos anos de 1990. Com uma história pessoal marcada por uma mediunidade que se revela ainda na sua infância, Pai Edivanei é uma espécie de "poliglota" das tradições que vão desde a Mina, como é praticada no Pará (Jeje Nagô) (DE LUCA, 2003; IPHAN, 2012), passando pela Umbanda e o Candomblé de nação Ketu.

O Terreiro de Mina Santa Bárbara tem um calendário regular de atividades, incluindo cerimônias e rituais públicos e obrigações privadas. Há um dia fixo na semana, normalmente às segundas-feiras, dedicado aos trabalhos da Cabocla Mariana ${ }^{12}$ e demais entidades ${ }^{13}$ que têm compromissos com a comunidade interna e externa a Casa.

O projeto de mapeamento mantém diálogo e parcerias de pesquisa e extensão de muitos anos com Pai Edivanei e toda a sua comunidade. A primeira oficina realizada pelo projeto aconteceu no espaço do Terreiro, onde reunimos professores da rede municipal de ensino, que atuavam em escolas quilombolas do planalto santareno, para uma formação no âmbito das diretrizes da lei 10.639/2003 ${ }^{14}$.

O Terreiro de Mina Santa Bárbara ${ }^{15}$, situado no bairro Aparecida, possui amplo pátio externo com solo exposto que permite o cultivo de plantas de grande porte. No centro do terreno existem um cajueiro, uma mangueira, vínica, andiroba, espada-de-são-jorge e comigo-

\footnotetext{
${ }^{10}$ Nosso projeto identificou a presença de cerca de 20 comunidades de Terreiros de religiões de matriz africana em Santarém, município com população de 294.580 pessoas em 2010, e com estimativa de 306.480 habitantes para 2020 (IBGE, 2010).

${ }^{11}$ As expressões próprias dos Terreiros em análise foram explicitadas entre aspas, e as palavras em Yorubá foram grafadas em itálico.

${ }^{12}$ Entidade bastante cultuada na região, originária de família da Turquia, é conhecida como Cabocla Mariana.

${ }^{13}$ Para mais detalhes sobre o panteão e, a respeito das particularidades dos mesmos nas comunidades de terreiro de Santarém, ver a dissertação de mestrado de Anderson Lucas da Costa Pereira, defendida em 2017, no Programa de Pós-Graduação em Antropologia Social (Museu Nacional-UFRJ).

${ }^{14}$ Lei 10.639/2003 que instituiu a obrigatoriedade do ensino da História e Cultura Africana e Afro-brasileira nos currículos escolares. Em 2011 havia uma coordenação de Educação Escolar Quilombola no município de Santarém que foi organizada pela intelectual negra Willivane Melo, ainda durante o governo da prefeita Maria do Carmo, do Partido dos Trabalhadores. O grupo interdisciplinar que foi montado na Coordenação de Educação Quilombola foi responsável por toda a política de vanguarda que foi criada em Santarém. Mais tarde, esses avanços serviram de base para as Diretrizes Curriculares Nacionais para Educação Escolar Quilombola.

${ }^{15}$ Para uma etnografia completa e inédita sobre o Terreiro Mina Santa Bárbara, ver a dissertação de mestrado de Anderson Lucas da Costa Pereira, defendida em 2017, no Programa de Pós-Graduação em Antropologia Social (Museu Nacional-UFRJ).
} 
ninguém-pode (aninga pará). A parte posterior do terreno apresenta um conjunto de plantas medicinais, como mutuquinha, pau de angola mirra, sabugueiro e elixir paregórico.

O sacerdote responsável pelo Terreiro, o Bàbálórìs a ${ }^{16}$ Edivanei de Oyá (figuras $01 \mathrm{e}$ 02), também é o responsável pela coleta e manuseio das plantas.

Figuras 1 e 2 - Bàbálórìsá Edivanei de Oyá durante visita ao seu quintal medicinal

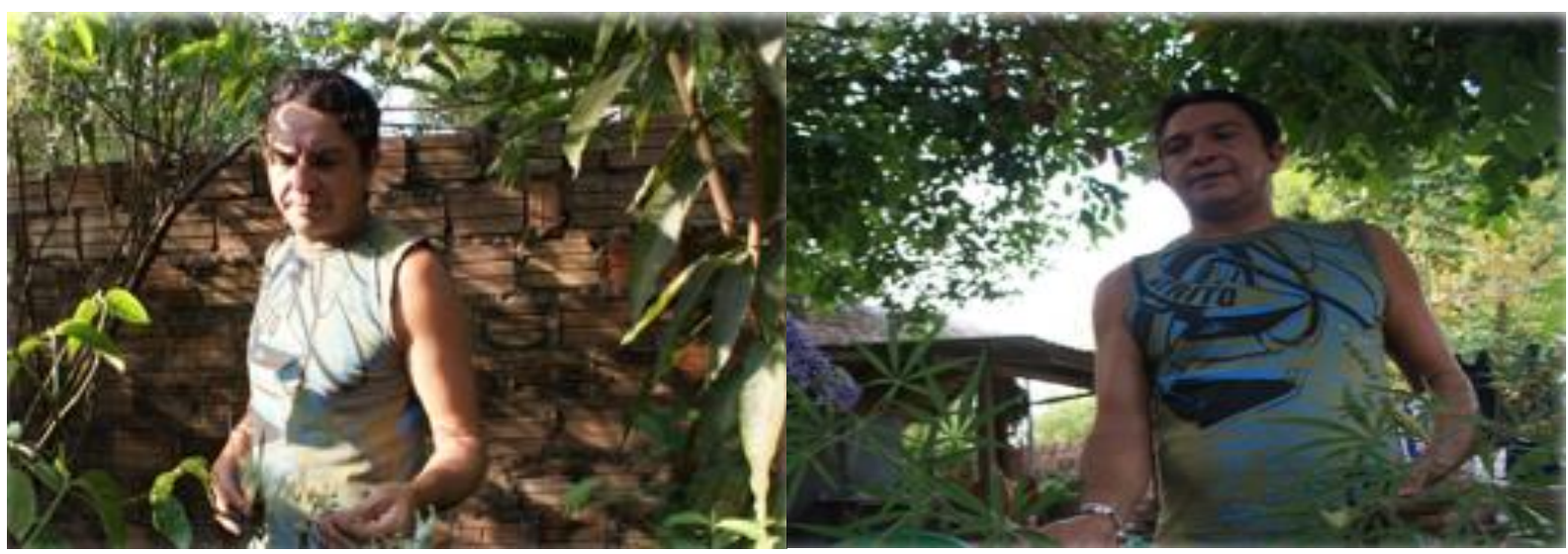

Fonte: Myrian Barboza, 2012.

Conforme seu relato ele aprendeu o ofício de manuseio das plantas com seu Pai e Mãe de Santo ${ }^{17}$, e com as entidades que o auxiliam quando o mesmo se encontra incorporado. Pai Edivanei, como é chamado, nos explicou que de maneira geral, as plantas utilizadas em rituais e cerimônias são classificadas em duas categorias: "plantas frias e plantas quentes".

As plantas frias são utilizadas in natura, sem a necessidade de tratamento prévio. Os vegetais que compreendem esta classe são as plantas aromáticas e são indicadas para banho do "corpo" e da "cabeça". As plantas do tipo "quente" recebem obrigatoriamente preparo prévio de aquecimento para posterior uso, como comigo-ninguém-pode e espada-de-são-jorge que são inicialmente fervidas. Esta classificação também foi encontrada em alguns Terreiros de Salvador, de acordo com Serra e colaboradores (2002).

\subsection{TERREIRO KWE OTO SINDOYA}

O Terreiro Kwe Oto Sindoya ${ }^{18}$ tem uma história de fundação que data de 1987, com a sua liderança a İyálòlrìsà Ozanélia de Oyá. O Terreiro de Sindoya como é conhecido na cidade, tem funcionamento regular com cerimônias e rituais públicos e privados ao longo de todo ano. A comunidade conta com dezenas de filhas e filhos de Santo, oferece uma função fixa em determinado dia da semana para o atendimento de caboclos, marinheiros, boiadeiros e outras entidades importantes na casa, e que fazem parte da linha de cura.

O Terreiro Kwe Oto Sindoya, localizado no bairro Caranazal, possui pátio externo com solo coberto por cimento, porém apresenta uma mangueira fixa ao solo e várias plantas em vasos, como alecrim de angola, akokó, aroeira, boldo, cana mansa, capim santo, elixir paregórico, espada-de-são-jorge, folha da costa, manjericão e peregum. A mangueira é muito utilizada para fixação de determinados conjuntos de assentamentos e "fundamentos". Estes últimos consistem num preparado especial de elementos materiais que são presos em galhos de árvores para adquirir força espiritual especial para uso posterior (figura 4).

\footnotetext{
${ }^{16}$ São responsáveis pelos templos religiosos conhecidos popularmente por "pais de santo" ou "zeladores".

${ }^{17}$ Autoridades máximas na hierarquia dos Terreiros.

${ }^{18}$ Para uma etnografia completa do Terreiro Kwe Oto Sindoya, ver a dissertação de mestrado de Beatriz Martins Moura, defendida em 2017, no Programa de Pós-Graduação em Antropologia, da Universidade de Brasília.
} 
Um dos $O g \tilde{a} s^{19}$ do Terreiro de Sindoya afirmou que as entidades do panteão Afroindígena, os caboclos e indígenas da Amazônia, apresentam elevado domínio de conhecimento das plantas, pois estes sempre atuaram em trabalho de cura, realizando uso dos vegetais para combater determinados tipos de enfermidades que atingem o corpo e a alma. Ele revelou que seus pais preparavam muitos remédios à base de plantas, principalmente as garrafadas. Destacou que anteriormente os medicamentos utilizados eram elaborados apenas com as cascas de paus e folhas. As plantas representam um elo essencial de conexão espiritual, e são respeitadas e veneradas como afirmou o próprio $O g \tilde{a}$ : "nós sabemos dar valor em cada pé de planta desses". No Terreiro de Sindoya há um sacerdote responsável pelo manuseio das plantas, Bàbálósányìn ou Iyálósányìn, como explicaremos a seguir.

\section{BÀBÁLÓSÁNYìN E IYÁLÓSÁNYÌN: GUARDIÕES DAS FOLHAS}

Nos Terreiros pesquisados foram encontradas pessoas designadas especialmente para realização do manuseio e coleta das plantas, denominadas como Bàbálósányìn ou Iyálósányìn. Os Bàbálósányìn ou Iyálósányìn são detentores (as) de um legado de saberes relacionados ao amplo universo botânico, que envolve desde os procedimentos de extração (período, locais, cantos de permissão, cantos de agradecimento), de conservação, como as práticas terapêuticas (forma de preparo, posologia, parte vegetal utilizada, etc.) (esquema 01).

O sacerdote do Terreiro de Mina Santa Bárbara advertiu sobre a importância da Iyálósányìn, em função de seu conhecimento minucioso sobre cada erva, pois a realização de combinações errôneas pode resultar em "choques" nos pacientes ou "aquizilamentos". De acordo com a Iya kékeré ${ }^{20}$ do templo Kwe Oto Sindoya, a designação do Iyálósányìn ou Bàbálósányìn ocorre por intermédio do Bàbálórìsá ou da İyálòlrìsà, que possui a incumbência de cumprir as determinações dos Orixás, incluindo iniciações e confirmação de cargos, no interior da sua comunidade. A qualificação da função de Iyálósányìn ou Bàbálósányìn é realizada através dos jogos de búzios, para as tradições que utilizam esse sistema divinatório, onde as filhas e filhos da Casa ${ }^{21}$ são convocados para "tomar cargo no Terreiro". Em 2014, o Bàbálósányìn do Terreiro de Sindoyá havia saído da casa e, por isso, a İya kékeré estava executando todas as atividades relacionadas ao manuseio das folhas. Apenas em situações muito particulares que outros membros do Terreiro, detentores de conhecimento e com função hierárquica importante, podem executar as atividades do Bàbálósányìn ou Iyálósányìn.

Os atributos do Bàbálósányìn ou Iyálósányìn também incluem a ida para as matas para realização dos $e b o ́ s^{22}$ de Òsányìn ${ }^{23}$. Trata-se de uma solicitação de permissão para que o Orixá Òsányìn libere as suas ervas necessárias e prescritas para as variadas cerimônias e rituais. Nos processos "iniciáticos", por exemplo, o Bàbálósányìn ou Iyálósányìn tem importante papel na coleta das plantas para o preparo da "cama do iniciado", a "cama bori", a "cama do odjbo" respeitando uma complexa performance que envolve rezas e cantos, e que pode durar vários dias.

\footnotetext{
${ }^{19}$ Responsável pela execução dos toques, através do atabaque, durante as cerimônias.

${ }^{20}$ Cargo feminino no Candomblé conferido àquela que ocupa o segundo posto na hierarquia da casa. Mãe pequena.

${ }^{21}$ Termo designado aos praticantes da religião.

${ }^{22}$ Banho especial geralmente realizado para os filhos da casa.

23 “Òsányìn Orixá masculino originário da cidade yorùbá de İràwò, que é dono das folhas, médico e conhecedor das propriedades medicinais da flora” (JAGUN, 2017:619).
} 
Esquema 01- Principais atribuições do Bàbálósányìn ou Iyálósányìn

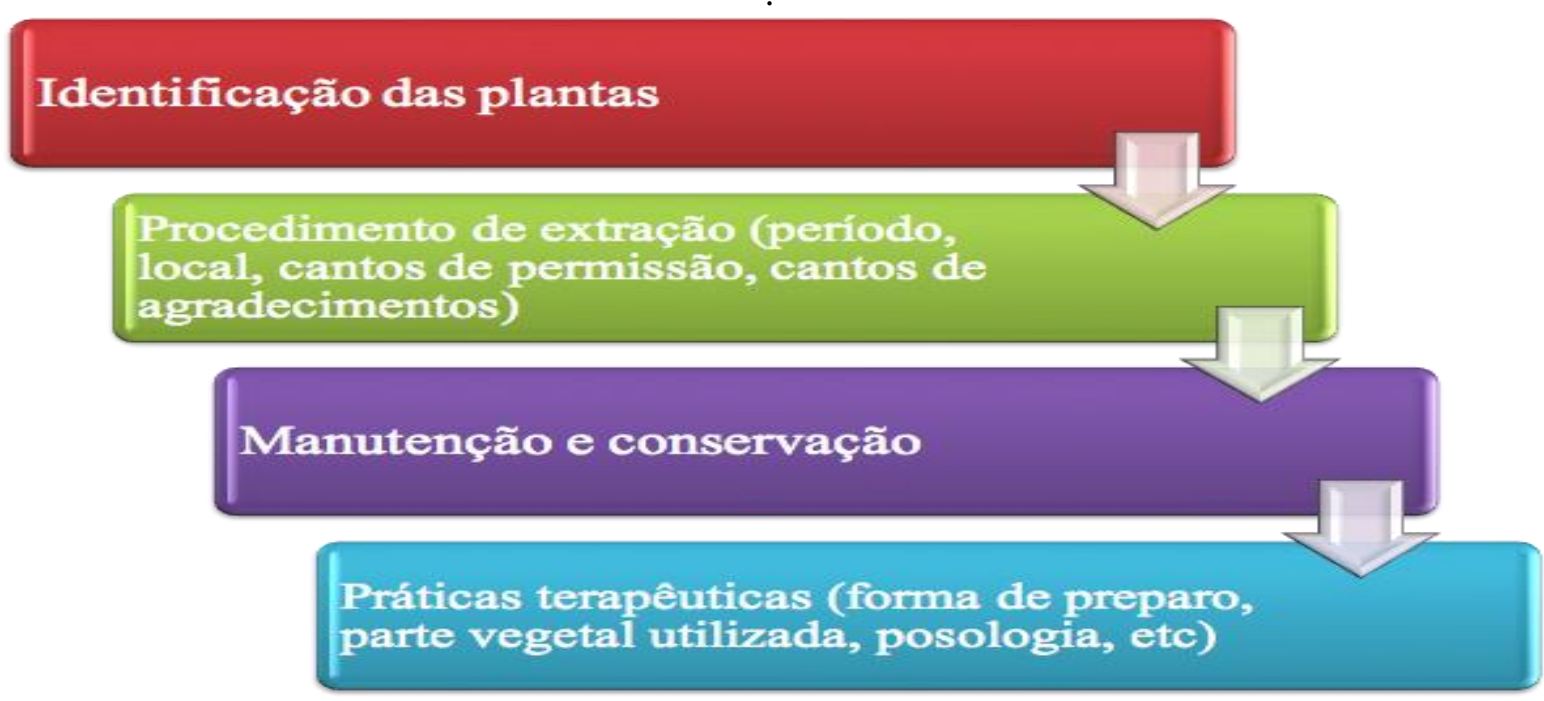

\section{PRÁTICAS DE FORTIFICAÇÃO E CURA NAS COMUNIDADES DE TERREIROS DE SANTARÉM}

No Terreiro de Mina Santa Bárbara, Pai Edivanei relatou ser comum a visita de pessoas em busca de tratamentos para curas fisiológicas e auxílio espiritual através do uso das plantas a fim de solucionar problemas de saúde muitas vezes não sanados pela medicina convencional. Nas pesquisas de Concone (2008), em Terreiros de Umbanda de São Paulo, os frequentadores realizavam busca simultânea pelos espaços científicos (consultórios médicos, hospitais, etc.) e pelos recintos mágico-religiosos (casas/Terreiros), o que motivou a pesquisadora a averiguar a lógica entrelaçada entre a concomitância de uso destas instituições. De acordo com ela, na Umbanda existe uma concepção unitária de corpo e globalizante de saúde, sem a fragmentação do sujeito e sem a incompatibilidade entre as práticas, o que permite a livre circulação de uma medicina a outra.

Nos Terreiros estudados em Santarém, o uso das plantas pode ser destinado para pessoas, animais e/ou entidades. Os animais domésticos também podem receber banhos e remédios preparados com ervas em diversos tipos de tratamentos. Para cada tipo de problema, de pessoa e de Orixá são utilizadas plantas específicas.

Dentre os principais procedimentos adotados com uso das plantas do Terreiro de Mina Santa Bárbara, foram destacados os seguintes: a) "comida de santo", que consiste na oferta de determinados alimentos para os Orixás ${ }^{24}$; b) o amaci, que consiste numa forma de limpeza de corpo; c) banhos, que podem ser de descarga, para "liberação de cargas negativas", ou atrativos, para "recebimento de cargas positivas"; d) ornamentação do espaço e dos altares, principalmente para ritos de iniciação e rituais festivos (figura 03); e) uso medicinal; f) "banho para lavar a cabeça", banho especial para os novos iniciados (esquema 02).

\footnotetext{
${ }^{24}$ Em 2019, realizamos a oficina "Epistemologias no Chão do Terreiro: Os Saberes da Alimentação do Santo e da Comunidade", que fez parte do 2o Simpósio Norte da Associação Brasileira de História das Religiões (ABHRNorte). Para maiores detalhes ler o texto de Leitão-Barboza e colaboradores (2021).
} 
Figura 03 - Altar ornamentado com plantas

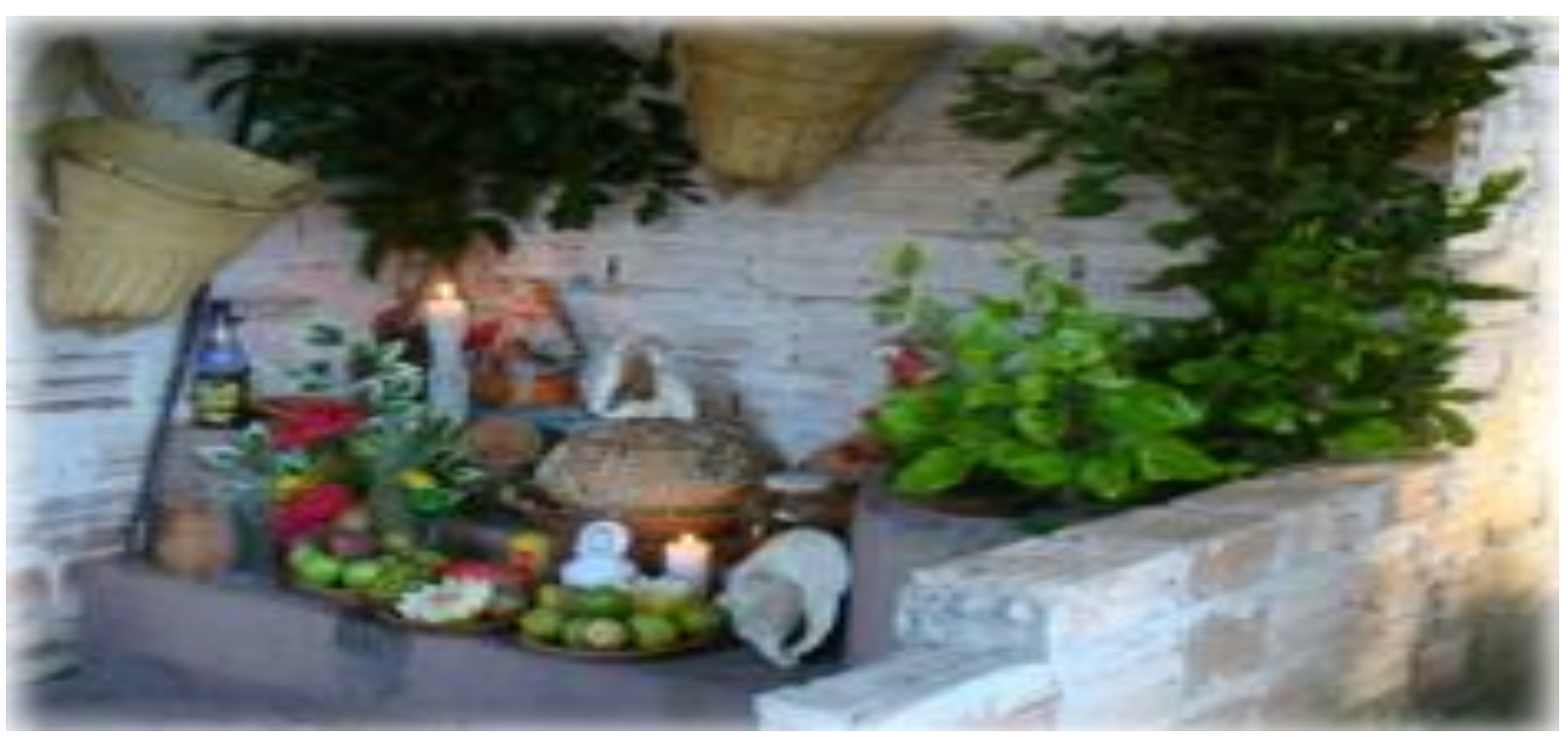

Fonte: Autora: Carla Munzanzu, 2012

Esquema 02 - Principais procedimentos adotados com uso das plantas no Terreiro de Mina Santa Bárbara

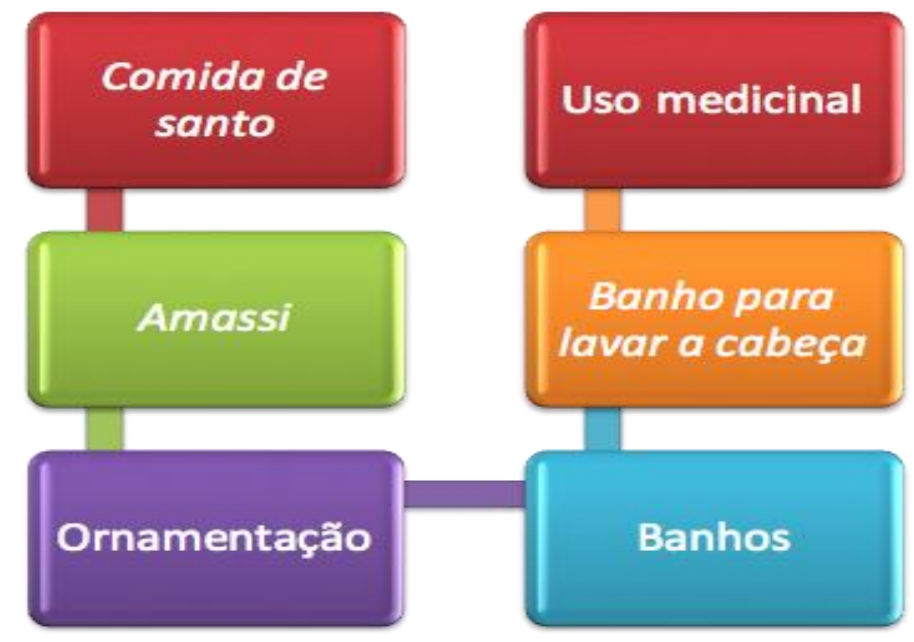

No Terreiro Kwe Oto Sindoya, dentre os principais procedimentos adotados para os cuidados de saúde e para fortificação espiritual através do emprego das plantas, foram destacados: a) garrafada, tipo de medicamento elaborado com plantas e armazenado em garrafas para posterior ingestão; b) ingestão de ervas através de chás e/ou xaropes; c) infusão de ervas; d) amaci; e) bori (bori branco ou obi d'água e bori vermelho ou obi de ejé) (esquema 03). 
Esquema 03- Principais procedimentos adotados com uso das plantas para os cuidados de saúde e fortificação espiritual no Terreiro Kwe Oto Sindoya.

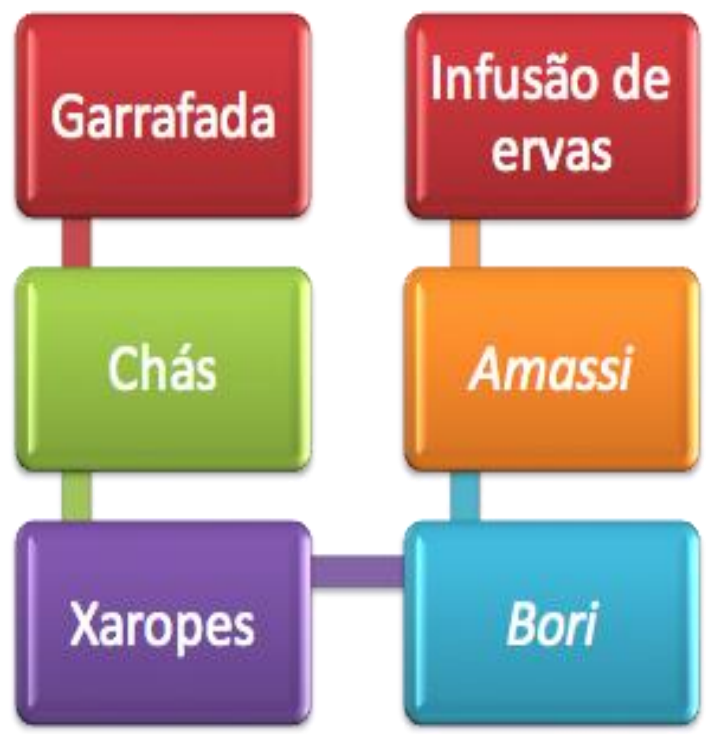

O amaci é um tipo de limpeza espiritual, fortificação, nos Terreiros aqui tratados é especialmente destinado aos ìyàwó ${ }^{25} \mathrm{com}$ a finalidade de propiciar recebimento de "bons fluidos do tempo", e consiste num banho com uso do "fundamento", um preparado especial.

O preparo requer uso de ervas específicas que são maceradas na água, acondicionadas em recipiente que posteriormente é pendurado em galhos, geralmente na mangueira existente no pátio do Terreiro. Estes preparados são dispostos em locais ritualmente escolhidos e estratégicos, como a copa das árvores e arbustos (figura 4), onde há ocorrência dos ventos, o que implica em maior recebimento de "energia" (axé). Após determinado tempo exposto às energias que são mobilizadas ritualmente, estes infusos podem ser utilizados nos banhos das cabeças dos İyàwó a fim de fortificá-las espiritualmente e torná-las mais próximas do seu Orixá, conforme relatado pela İya kèkerè (informação verbal) ${ }^{26}$ :

A mamãe utiliza os seus galhos (mangueira), uma parte bem alta, para pendurar um fundamento justamente pra pessoa pegar bons fluidos do tempo, tudo que tiver referente ao tempo, aonde tá mais lá em cima fica mais fácil de se absorver a positividade, levar a negatividade e ficar mais próximo às divindades que nós acreditamos (Informação verbal da Ìya kèkerè do Terreiro Kwe Oto Sindoya, Izonara Souza).

25 "İyàwó cargo conferido no Candomblé aos iniciados no culto aos Orixás" (JAGUN, 2017:554).

${ }^{26}$ Informação fornecida pela Ìya kèkerè Izonara do Terreiro do Kwe Oto Sindoyá em abril de 2014. 
Figura 4 - Fundamento preso em galho de mangueira presente no próprio Terreiro.

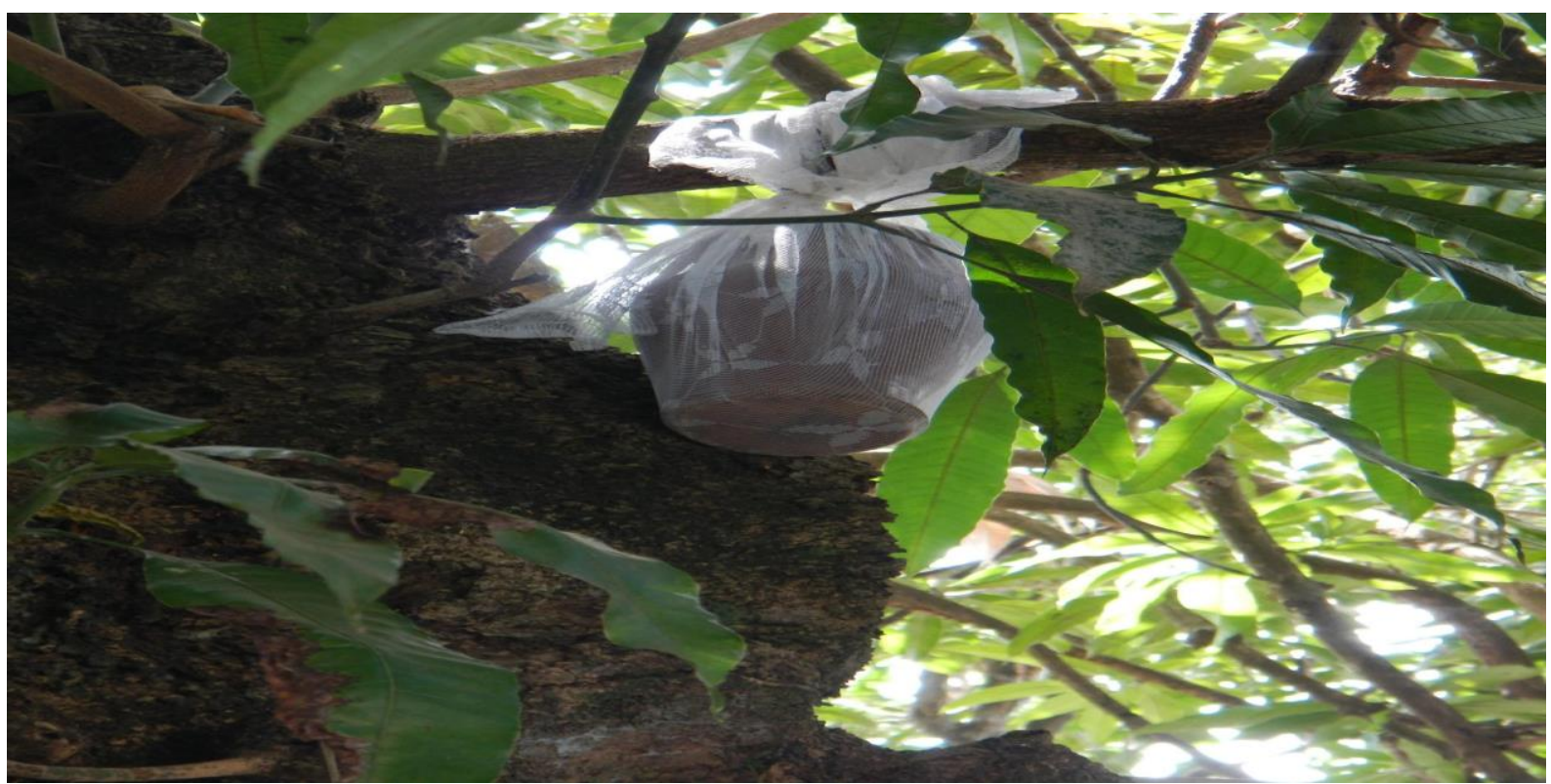

Fonte: Anne Py-Daniel, 2012.

Os boris consistem em tratamentos de limpeza e fortificação indicados para os que possuem problemas de saúde e/ou problemas de outra ordem. Durante o jogo de ifáa $a^{27}$ o Orixá pode indicar a necessidade de realização de bori para a pessoa consultada. A İya kèkerè mencionou a existência de dois tipos de bori: bori branco (obi d'água) e bori vermelho (obi de ejé). O bori branco pode ser destinado aos filhos da casa e aos clientes. O processo de bori branco para os filhos da casa inclui a realização de banhos, ebós, e recolhimento durante dois dias no ronkó ${ }^{28}$. Este recolhimento tem por finalidade proporcionar ao İyàwó a resolução dos seus problemas externos e concentração para os anseios de melhoria.

A İya kèkerè nos relatou que sua filha de 11 anos já havia "tomado" obi d'água para garantir o equilíbrio de sua saúde futura. A İyálòlrìsà havia sido notificada, através de jogo de ifá, que esta criança poderia desencadear sérios problemas de saúde. Destarte, a criança recebeu ebó e obi d'água com a função de "equilibrar o seu odù" 29 , uma maneira de invocar saúde e produzir uma reorientação profunda das forças do destino de cada pessoa. O bori vermelho (obi de ejé), explicou a Ìya kèkerè, consiste numa limpeza mais profunda e demorada. Neste procedimento ocorre o sacrifício de animais (geralmente aves), a realização de oferendas, banhos (ebó) e recolhimento da filha (o) da casa durante sete dias ou mais no ronkó, a depender do tipo de obrigação que será realizada.

\footnotetext{
27 "Oráculo feito com coquinhos do dendezeiro, considerado também como divindade, dada a sua relevância. Muitas vezes esta palavra é utilizada como sinônimo de Òrúnmilà, que na verdade é a divindade da adivinhação. Desta forma, o Oráculo de Ifá, é considerado como a própria presença de Òrúnmilà no mundo" (JAGUN, 2017: 600).

${ }^{28}$ Cômodo especial utilizado para recolhimentos das iniciadas.

29 “Odù, destinos, caminhos, signos do oráculo de Ifá retratados através de poemas” (JAGUN, 2017:703).
} 
Esquema 04- Exemplos de procedimentos de limpeza e fortificação que utilizam plantas

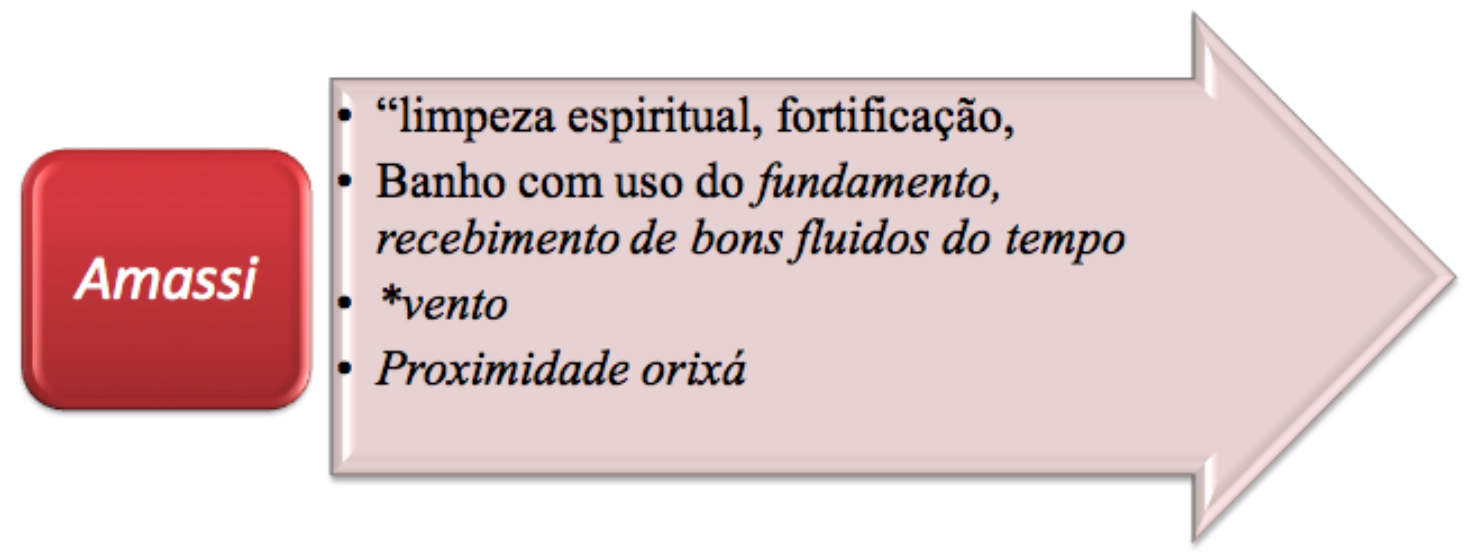

4 ÒSÁNYÌN: "SENHOR DAS ERVAS"

"Acredita-se que Ossain é o princípio ativo que circula em todos os vegetais" (SOUZA JUNIOR, 2011, p. 77).

Ossaim, filho de Nanã e irmão de Oxumarê, Euá e Obaluaê, era o senhor das folhas, da ciência e das ervas, o orixá que conhece o segredo da cura e o mistério da vida.

Todos os orixás recorriam a Ossaim para curar qualquer moléstia, qualquer mal do corpo. Todos dependiam de Ossaim na luta contra a doença. Todos iam à casa de Ossaim oferecer seus sacrificios.

Em troca Ossaim lhes dava preparados mágicos: banhos, chás, infusões, pomadas abô, beberagens.

Curava as dores, as feridas, os sangramentos; as disenterias, os inchaços e fraturas; curava as pestes, febres, órgãos corrompidos; limpava a pele purulenta e o sangue pisado; livrava o corpo de todos os males.

(Prandi, 2001: 153)

Òsányìn é considerado o Orixá conhecedor das ervas, o dono de todas as folhas sagradas e da mata. Este Orixá representa o pai criador das ervas e sua morada é na mata. Para realização de qualquer atividade que envolva uso das plantas é necessário solicitar autorização e licença para Òsányìn. A İya kèkerè do Terreiro Kwe Oto Sindoya, nos contou que para realização dos ebó das (os) filhas (os) que estão recolhidas (os), solicita-se primordialmente a autorização para Òsányìn, e posteriormente o ebo é levado para a mata junto com outros objetos que vão compor a oferenda. Trata-se de um complexo ritual de autorização para coleta e uso de determinadas folhas e demais elementos de um sistema botânico muito bem definido. Desta maneira, ela nos explica, Òsányìn permite que as folhas saiam do seu ambiente, da "sua essência", do "local onde nasceu" para servir ao Orixá em uma casa de axé. Ainda de acordo com o relato da İya kèkerè (informação verbal) ${ }^{30}$, para qualquer atividade que envolva o uso das folhas, cascas, flores, galhos e frutos é necessário profundo conhecimento e envolvimento prático com a religião, além de uma noção apurada da integralidade e conexão entre todas as dimensões da existência.

\footnotetext{
${ }^{30}$ Informação fornecida pela İya kèkerè Izonara, do Terreiro Kwe Oto Sindoyá em junho de 2014.
} 
É lógico que tem pessoas que matam e que derrubam, mas sem ter um conhecimento por que não tem um envolvimento, lógico que com o envolvimento em uma religião que é totalmente voltada à natureza e a elementos da natureza, a gente já tem todo esse cuidado, todo esse respeito né (Informação verbal da Ìya kèkerè do Terreiro Kwe Oto Sindoya, Izonara Souza).

\section{OMOLU: "PROVEDOR DA SAÚDE E DA DOENÇA"}

Omolu é dono do mundo, é considerado o Orixá que pode trazer a doença e a cura, e segundo a İya kèkerè "ele traz a vida e a morte". Nas muitas tradições terapêuticas das comunidades de Terreiro, quando uma pessoa se encontra enferma roga-se pela melhoria do estado de saúde da mesma para os seus Orixás, e também para Omolu. No Terreiro Kwe Oto Sindoya participamos da cerimônia do Olubajée, que é realizada anualmente dentro do calendário litúrgico, e tem como função render homenagens a Omolu com um banquete de iguarias ofertado por todos os Orixás do panteão.

Nesta ocasião festiva e de muita devoção, pede-se saúde e vida longa (figura 05). Antes que cada convidado inicie o seu saboroso "jantar", todos são chamados ao barracão, onde a cerimônia pública está acontecendo e, um a um, se aproximam do Orixá que lentamente passa uma porção de pipocas pelo seu corpo, num ritual de purificação. Em seguida, somos orientadas a ingerir uma pequena quantidade que podemos pegar dentro de um grande balaio de bambu que foi colocado no centro do barracão.

Este ato específico simboliza a busca pela saúde, sendo que outros pedidos, como a obtenção de emprego, o pagamento de dívidas, também podem ser requeridos. Antes da realização do tabuleiro, aberto ao público, os filhos da casa já estavam realizando cerimônia interna, com prática de ebó e solicitação de saúde.

Figura 5 - Tabuleiro de Omolu

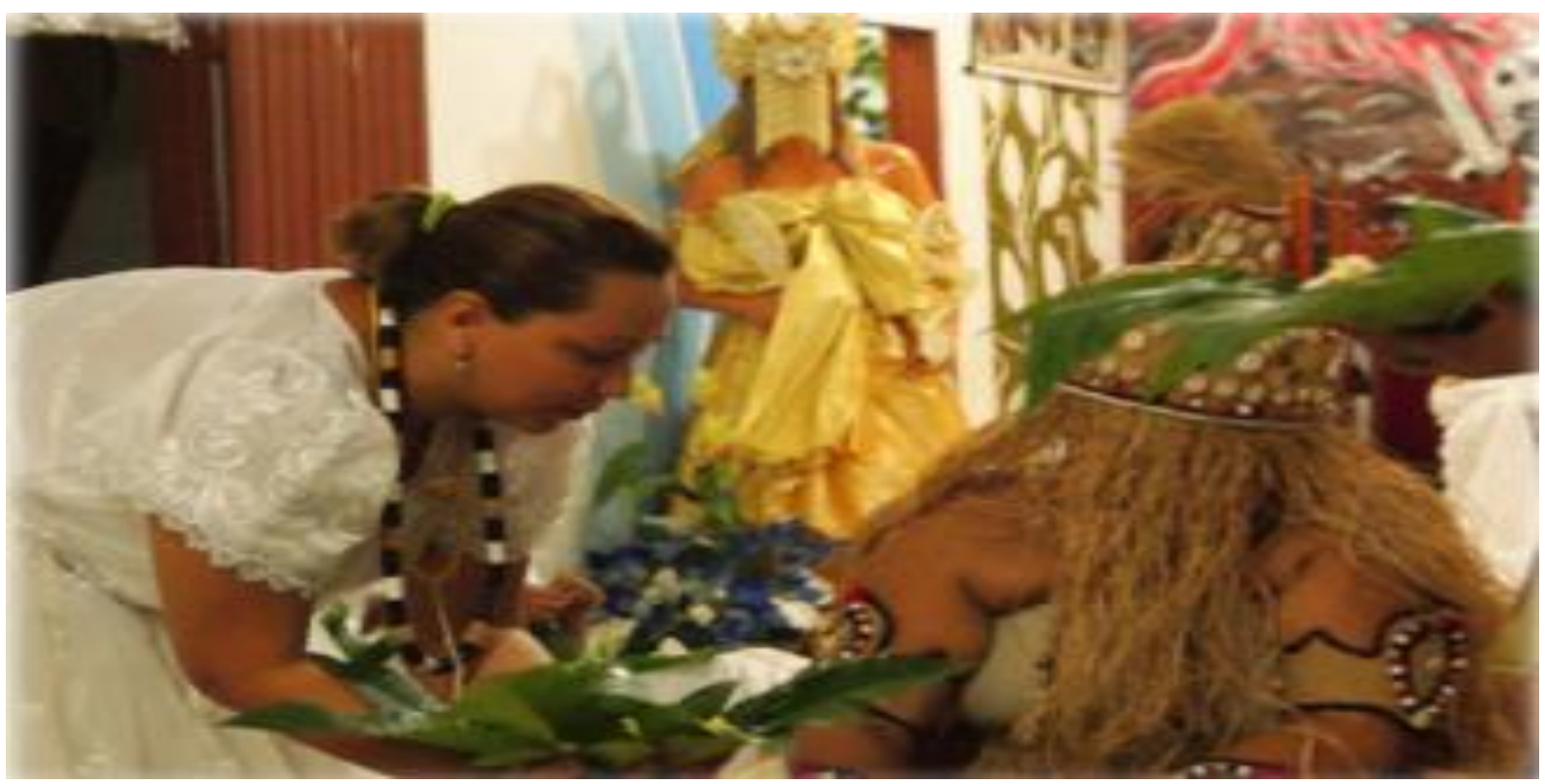

Fonte: Myrian Barboza, 2014.

\section{DONA MARIANA: “CURADORA DAS ENFERMIDADES"}

Dona Mariana representa uma entidade cabocla muito cultuada em Terreiros de Umbanda e Mina da região amazônica (MOURA, 2017) e também atua na cura de 
enfermidades, como relatado no Terreiro Kwe Oto Sindoya. Durante consulta no Terreiro, uma frequentadora apresentou problemas de saúde com feridas que se espalhavam pelo corpo, e na ocasião a cabocla dona Mariana interveio através da aplicação de saliva e cinza de cigarro no próprio ferimento. Alguns dias depois da consulta, as feridas foram cicatrizadas conforme descrito pela İya kèkerè Izonara.

No Terreiro Kwe Oto Sindoya, em momentos de consulta terapêutica, o procedimento inicial consiste na realização de jogo de búzios para as orientações sobre o que deverá ser feito. Em muitos casos são aplicados ebó para egúngún ${ }^{31}$, para que as doenças sejam levadas embora e a pessoa envolvida possa gozar de plena saúde. Quando as enfermidades são espirituais e, sendo assim, não são passíveis de serem diagnosticadas pelos médicos, a prescrição deve ser, entre outros procedimentos, manter equilíbrio do od $\grave{u}^{32}$ para que o espírito fique, dessa maneira, mais fortificado e positivamente energizado. A prática de cura por intermédio de Dona Mariana foi pouco citada, sendo necessários estudos futuros para melhor compreensão de seu papel nas ações terapêuticas dos Terreiros pesquisados. Uma das narrativas da Ìya kèkerè (informação verbal) ${ }^{33}$ relembra ações de cura de Dona Mariana:

Eu já vi durante a minha vida aqui dentro, Dona Mariana curar uma enfermidade. Ela já fez cura com a saliva ou então com a cinza de cigarro, ela mesma fumando conversou e conversou e depois aquele cinza todinha ela colocou dentro. Se amanhã você vem aqui já estava seca e depois fechou, lógico gradativamente... Ela energizou a saliva da mamãe. A mamãe não é santa para ela curar ninguém, de onde a gente vai tirar da cabeça que isso poderá curar alguma coisa, na lógica não existe isso, e isso já aconteceu [...] (Informação verbal da İya kèkerè do Terreiro Kwe Oto Sindoya, Izonara Souza).

\section{LEVANTAMENTO DAS PRINCIPAIS ETNOSPÉCIES VEGETAIS UTILIZADAS NOS TERREIROS}

Durante esta pesquisa realizamos um levantamento preliminar, que necessita de continuidade com estudos futuros para aprofundamento da compreensão e identificação científica da diversidade de plantas utilizadas nas religiões de matriz africana na Amazônia. Neste levantamento preliminar procuramos verificar as diferentes formas de uso das plantas, incluindo, principalmente, as plantas utilizadas nos processos terapêuticos das duas comunidades de Terreiros pesquisadas.

\subsection{TERREIRO DE MINA SANTA BÁRBARA}

No Terreiro de Mina Santa Bárbara as principais plantas utilizadas foram sistematizadas em tabela específica (tabela 1). Segundo relato de Pai Edivanei, sacerdote do Terreiro, todas as plantas citadas são frequentemente utilizadas. $\mathrm{O}$ uso das plantas pode ser destinado para pessoas, animais e/ou entidades. Desta forma, os animais domésticos também podem receber banhos e remédios preparados com ervas em diversos tipos de tratamento como "retirada de mal olhado" e quando o animal encontra-se triste, sem alimentar-se.

\subsection{TERREIRO KWE OTO SINDOYA}

\footnotetext{
${ }^{31}$ Egúngún - "Culto aos espíritos ancestrais masculinos de determinada família ou comunidade." (JAGUN, 2017:596).

${ }^{32}$ Energia negativa, segundo informações obtidas no Terreiro.

${ }^{33}$ Informação fornecida pela İya kèkerè Izonara, do Terreiro Kwe Oto Sindoyá em junho de 2014.
} 
No Terreiro Kwe Oto Sindoya, as principais plantas utilizadas também foram organizadas na tabela 1. Algumas plantas são utilizadas para banho por serem aromáticas, "ervas cheirosas", como alecrim e espada-de-são-jorge. O capim santo e erva cidreira, preparados na forma de chá, fazem parte da dieta dos iniciados, os quais experimentam inúmeras restrições alimentares, pois se encontram em período de iniciação conforme relato de um dos nossos interlocutores. São excluídos da dieta os seguintes itens: café, refrigerante, chá mate e chás comercializados em caixinha.

As principais folhas utilizadas para ornamentação do Terreiro são as folhas de akokô, de mangueira (Òró Òyìnbó) e palmeira. A folha de akokó, não recomendada para banho, é empregada no preparo do altar do Orixá dos iniciados. A mangueira é considerada árvore sagrada e é usada também para ornamentação e limpeza do Terreiro. As palmeiras propiciam "força de axé", porém não devem ser compradas, devem ser resultantes de doações. Determinadas plantas são consideradas como sagradas e, desta forma, não podem faltar nas cerimônias especiais. As folhas da aroeira, conforme revelação da İya kekerê, tem finalidade de purificar a matéria do iaô até a consagração do orixá". Enquanto o peregun é utilizado para as "puxadas de orixá do iniciado", dentre outras finalidades.

Tabela 01 - Principais plantas utilizadas nas comunidades de Terreiros Santa Bárbara e no Terreiro Kwe Oto Sindoya

\begin{tabular}{|c|c|c|c|c|c|c|}
\hline $\mathbf{N}$ & $\begin{array}{c}\text { Nomenclatura } \\
\text { vernacular }\end{array}$ & Finalidade & $\begin{array}{c}\text { Partes } \\
\text { utilizadas }\end{array}$ & $\begin{array}{c}\text { Formas de } \\
\text { preparo }\end{array}$ & $\begin{array}{c}\text { Local de } \\
\text { aquisição }\end{array}$ & $\begin{array}{c}\text { Horário } \\
\text { de coleta }\end{array}$ \\
\hline 01 & Acocô & $\begin{array}{l}\text { Preparo do } \\
\text { altar do orixá } \\
\text { (referente à } \\
\text { cerimônia dos } \\
\text { iniciados) }\end{array}$ & Folhas & & & \\
\hline 02 & Alecrim & $\begin{array}{l}\text { Banho } \\
\text { Perfume } \\
\text { Defumação }\end{array}$ & & $\begin{array}{l}\text { Chá } \\
\text { Infusão }\end{array}$ & & \\
\hline 03 & $\begin{array}{l}\text { Alecrim-do- } \\
\text { norte }\end{array}$ & $\begin{array}{l}\text { Harmonia para } \\
\text { o lar }\end{array}$ & Folhas & $\begin{array}{l}\text { Após maceração } \\
\text { das folhas com } \\
\text { água espalhar na } \\
\text { casa } \\
\text { Chá } \\
\text { Banho }\end{array}$ & Vizinho & \\
\hline 04 & Andiroba & $\begin{array}{l}\text { Anti- } \\
\text { inflamatório }\end{array}$ & & Massagem & & \\
\hline 05 & Anil estrelado & $\begin{array}{l}\text { Dores no } \\
\text { estômago }\end{array}$ & Flor seca & Chá & $\begin{array}{l}\text { Quintal do } \\
\text { Terreiro } \\
\text { Loja "Casa do } \\
\text { tempero" }\end{array}$ & $\begin{array}{l}\text { Manhã ou } \\
\text { tarde }\end{array}$ \\
\hline 06 & Aroeira & $\begin{array}{l}\text { Proteção do } \\
\text { Terreiro; } \\
\text { "Planta } \\
\text { sagrada para } \\
\text { fazer Iaô" }\end{array}$ & & & & \\
\hline 07 & Boldo & Fígado & & Chá & & \\
\hline 08 & Cajueiro & $\begin{array}{l}\text { Gripe } \\
\text { Catarro no } \\
\text { peito } \\
\text { Tuberculose } \\
\text { Infecção } \\
\text { feminina }\end{array}$ & Entrecasca & $\begin{array}{l}\text { Chá } \\
\text { Xarope com mel } \\
\text { e outras plantas } \\
\text { Asseio para } \\
\text { mulheres }\end{array}$ & $\begin{array}{l}\text { Quintal do } \\
\text { Terreiro }\end{array}$ & $\begin{array}{l}\text { Manhã ou } \\
\text { à tarde } \\
\text { antes do } \\
\text { pôr do } \\
\text { sol; }\end{array}$ \\
\hline
\end{tabular}




\begin{tabular}{|c|c|c|c|c|c|c|}
\hline 09 & Capim santo & & & $\begin{array}{l}\text { Chá } \\
\text { Banho }\end{array}$ & & \\
\hline 10 & $\begin{array}{l}\text { Catinga de } \\
\text { mulata }\end{array}$ & $\begin{array}{l}\text { Estômago } \\
\text { Aromatizante }\end{array}$ & Folhas & $\begin{array}{l}\text { Chá } \\
\text { Banho }\end{array}$ & $\begin{array}{l}\text { Quintal do } \\
\text { Terreiro }\end{array}$ & \\
\hline 11 & Cidreira & & & $\begin{array}{l}\text { Chá } \\
\text { Banho }\end{array}$ & & \\
\hline 12 & Cipó alho & $\begin{array}{l}\text { Anti- } \\
\text { inflamatório } \\
\text { Cicatrizante }\end{array}$ & & $\begin{array}{l}\text { Chá } \\
\text { Banho }\end{array}$ & $\begin{array}{l}\text { Quintal do } \\
\text { Terreiro }\end{array}$ & \\
\hline 13 & $\begin{array}{l}\text { Colônia de } \\
\text { oxum } \\
\text { (jardineira) }\end{array}$ & $\begin{array}{l}\text { Problema no } \\
\text { coração }\end{array}$ & Flor & Banho & & \\
\hline 14 & $\begin{array}{l}\text { Comigo- } \\
\text { ninguém-pode } \\
\text { (Aninga Pará) }\end{array}$ & & & Banho & & \\
\hline 15 & $\begin{array}{l}\text { Elixir } \\
\text { paregórico }\end{array}$ & $\begin{array}{l}\text { Febre } \\
\text { Estômago } \\
\text { Intestino }\end{array}$ & & Chá & & \\
\hline 16 & $\begin{array}{l}\text { Espada-de-são- } \\
\text { Jorge }\end{array}$ & $\begin{array}{l}\text { Proteção do } \\
\text { Terreiro, das } \\
\text { pessoas e das } \\
\text { moradias (tirar } \\
\text { mau olhado e } \\
\text { defesa do } \\
\text { corpo); }\end{array}$ & Folhas & $\begin{array}{l}\text { Chá } \\
\text { Maceração } \\
\text { Banho }\end{array}$ & $\begin{array}{l}\text { Quintal do } \\
\text { Terreiro }\end{array}$ & \\
\hline 17 & Folha da costa & & & $\begin{array}{l}\text { Coloca na } \\
\text { cabeça }\end{array}$ & & \\
\hline 18 & $\begin{array}{l}\text { Incenso de } \\
\text { jurema }\end{array}$ & Aromática & Folhas secas & $\begin{array}{l}\text { Defumação } \\
\text { Banho }\end{array}$ & $\begin{array}{l}\text { Quintal do } \\
\text { Terreiro }\end{array}$ & $\begin{array}{l}\text { Manhã ou } \\
\text { tarde }\end{array}$ \\
\hline 19 & Iroco & & & & & \\
\hline 20 & Japana roxa & $\begin{array}{l}\text { Cólicas de } \\
\text { crianças } \\
\text { recém- } \\
\text { nascidas e } \\
\text { adultos; }\end{array}$ & $\begin{array}{l}\text { Folhas } \\
\text { Galhos }\end{array}$ & Chá & $\begin{array}{l}\text { Pequenos } \\
\text { produtores }\end{array}$ & $\begin{array}{l}\text { Manhã ou } \\
\text { tarde }\end{array}$ \\
\hline 21 & Mangueira & $\begin{array}{l}\text { Cicatrizante } \\
\text { Limpeza do } \\
\text { Terreiro } \\
\text { Ornamentação } \\
\text { Energizante da } \\
\text { casa/Terreiro } \\
\end{array}$ & $\begin{array}{l}\text { Entrecasca } \\
\text { Fruto } \\
\text { Folhas }\end{array}$ & $\begin{array}{l}\text { Chá } \\
\text { Xarope }\end{array}$ & $\begin{array}{l}\text { Quintal do } \\
\text { Terreiro }\end{array}$ & $\begin{array}{l}\text { Manhã ou } \\
\text { tarde }\end{array}$ \\
\hline 22 & Manjericão & $\begin{array}{l}\text { Abre caminho } \\
\text { para os } \\
\text { negócios e } \\
\text { para o amor } \\
\text { Alimentação }\end{array}$ & Banho & & $\begin{array}{l}\text { Quintal do } \\
\text { vizinho }\end{array}$ & $\begin{array}{l}\text { Horários } \\
\text { variam de } \\
\text { acordo } \\
\text { com a } \\
\text { nacãa }\end{array}$ \\
\hline 23 & Mirra & $\begin{array}{l}\text { Benzimento } \\
\text { Estômago }\end{array}$ & Planta seca & $\begin{array}{l}\text { Maceração com } \\
\text { água } \\
\text { Banho } \\
\text { Defumação } \\
\text { Chá }\end{array}$ & & Manhã \\
\hline 24 & Mutuquinha & $\begin{array}{l}\text { Proteção } \\
\text { Dor de ouvido }\end{array}$ & $\begin{array}{l}\text { Banho } \\
\text { Chá } \\
\text { Maceração }\end{array}$ & & $\begin{array}{l}\text { Quintal do } \\
\text { Terreiro }\end{array}$ & \\
\hline
\end{tabular}




\begin{tabular}{|c|c|c|c|c|c|c|}
\hline & & $\begin{array}{l}\text { Dor de } \\
\text { estômago }\end{array}$ & & & & \\
\hline 25 & Palmeira & $\begin{array}{l}\text { Proteção } \\
\text { Ornamentação }\end{array}$ & Folha & & & \\
\hline 26 & Pau de angola & $\begin{array}{l}\text { Dor no } \\
\text { estômago } \\
\text { Cicatrização } \\
\text { de feridas }\end{array}$ & $\begin{array}{l}\text { Maceração } \\
\text { Chá } \\
\text { Banho }\end{array}$ & & $\begin{array}{l}\text { Quintal do } \\
\text { Terreiro }\end{array}$ & $\begin{array}{l}\text { Manhã ou } \\
\text { tarde }\end{array}$ \\
\hline 27 & Pau ferro & Ornamentação & & & $\begin{array}{l}\text { Mata da } \\
\text { Rodovia } \\
\text { Everaldo } \\
\text { Martins }\end{array}$ & \\
\hline 28 & Peregun & $\begin{array}{l}\text { Puxada de } \\
\text { Oya ou Ogum }\end{array}$ & & & & \\
\hline 29 & Quina quina & Malária & Planta toda & Chá & & \\
\hline 30 & Sabugueiro & $\begin{array}{l}\text { Sarampo } \\
\text { Catapora }\end{array}$ & Folhas & Chá & $\begin{array}{l}\text { Quintal do } \\
\text { Terreiro }\end{array}$ & $\begin{array}{l}\text { Manhã ou } \\
\text { tarde }\end{array}$ \\
\hline 31 & $\begin{array}{l}\text { Vindica pajé } \\
\text { (vinho de } \\
\text { capajé, colônia } \\
\text { da oxum, } \\
\text { jardineira) }\end{array}$ & $\begin{array}{l}\text { Calmante } \\
\text { Estômago } \\
\text { Adquirir sorte }\end{array}$ & $\begin{array}{l}\text { Raiz } \\
\text { Folhas }\end{array}$ & $\begin{array}{l}\text { Chá } \\
\text { Banho } \\
\text { Coloca na } \\
\text { carteira } \\
\text { Banho }\end{array}$ & $\begin{array}{l}\text { Quintal do } \\
\text { Terreiro }\end{array}$ & \\
\hline
\end{tabular}

Fonte: Elaborada pelas autoras do presente artigo.

\section{CONSIDERAÇÕES FINAIS}

O mesmo pai de santo que havia cuidado de minha mãe em Cachoeira veio até Água Negra para orientar a transferência de uma casa para outra. Na casa velha havia vivido um homem poderoso que movimentava energias entre o mundo dos vivos e dos mortos. Moveu sentimentos bons e ruins, curou a terra, curou pessoas, evocou espíritos da natureza. Então tudo que havia vivido, todo o movimento de seu mundo de fé estava pairando naquele espaço, e deveria ser encaminhado a um destino. Ela seria desmanchada. Retiraram portas, janelas e o junco que recobria o teto. O pai de santo bateu com ervas nas paredes e entoou cantigas que nunca havia escutado nas brincadeiras de jarê.

(Vieira Junior, 2019:167)

Nas duas comunidades de Terreiros pesquisadas percebemos e vivenciamos uma intensa conexão entre plantas e os praticantes, sendo vital sua existência e acesso para a garantia da perpetuação da religião. Nestes espaços existem pessoas específicas, Bàbálósányìn ou Iyálósányìn, com atribuições especiais que envolvem o manuseio e o cuidado das plantas. Estes responsáveis possuem um vasto conhecimento a respeito da coleta, usos, preparo e prescrição das plantas.

Os procedimentos que envolvem uso das plantas, seja de rotina ou ritualísticos, requerem cuidados prévios de obtenção e manutenção dos vegetais. Assim, antes da realização de qualquer atividade que demande acesso às folhas, faz-se necessário uma série de rituais específicos dedicados à Òsányìn, o orixá que é dono de todos os segredos das ervas, guardião e protetor dos vegetais e da floresta. O processo de consentimento de uso de plantas, folhas, cascas, flores, frutos, envolve a ida até a mata com realização de um conjunto de performances, em geral, coletivas, mas não somente, e que incluem cânticos e a manipulação de certos elementos como velas e fumo, grãos e líquidos. Destarte, o uso litúrgico das plantas nas 
religiões de matriz africana parece aludir a uma perspectiva ecológica dos ambientes, numa classificação ética, sobretudo através do respeito e manutenção destes espaços em longo prazo.

No conjunto de saberes fitoculturais do universo afro existem entidades singulares responsáveis pela liberação ao acesso às plantas, promoção da saúde e de curas terapêuticas. O orixá Omolu, por exemplo, representa a divindade provedora da saúde e da doença, responsável pelo bem-estar espiritual das pessoas. A cabocla Dona Mariana constitui-se como importante representante espiritual das terapias de cura, sendo também responsável por algumas intervenções de promoção à saúde. Estas entidades atuam como interlocutores especiais entre o mundo físico e sobrenatural nas questões relacionadas à promoção de saúde.

Para além do legado fitocultural, ações de respeito, manutenção, uso e conservação das plantas, as religiões de matriz africana desempenham relevante papel no sentido do coletivo e do cuidado mútuo entre seus praticantes e visitantes. Por meio da promoção de um sistema terapêutico de promoção da saúde e de cura, baseado nas ações de fortificação psíquica e física, as comunidades religiões de matriz africana abraçam e abarcam todos que a elas recorrem, conforme alega Souza Junior (2011, p.77):

É, pois, a partir da noção de comunidade, da grande roda que gira no sentido antihorário, que as religiões de matriz africana não apenas procuram significar a doença, restabelecendo o equilíbrio, mas também buscam de forma inclusiva agregar aqueles e aquelas colocados à margem da sociedade.

Assim, as comunidades tradicionais de Terreiro no Brasil sobrevivem, resistem, se fortalecem e se perpetuam por meio de sua essência cosmológica e filosófica de respeito e valorização das plantas, pois conforme nos cantam e contam as lideranças afro-religiosas "sem as plantas, a religião não existiria".

\section{AGRADECIMENTOS}

Somos especialmente gratas às mães, pais e zeladores das Casas e Terreiros no oeste do Pará por todas as colaborações e acolhidas ao longo de mais de 10 anos de nossas interações e atividades de pesquisa e extensão. Agradecemos aos membros participantes do projeto Anderson Pereira, Beatriz Moura, Telma Bermerguy e Rosana Sawaki pelas vivências e aprendizados. À nossa amiga Anne Rapp Py-Daniel agradecemos pelo incentivo e apoio em nossas atividades.

\section{REFERÊNCIAS}

ALBUQUERQUE, Ulysses Paulino; ANDRADE, Laíse de Holanda Cavalcanti. Plantas medicinais no Brasil: a contribuição africana. Revista Racine, São Paulo, v. 85, p.88-93. 2005 .

ALBUQUERQUE, Ulysses Paulino; LUCENA, Reinaldo Farias Paiva de; ALENCAR, Nelson Leal. Métodos e técnicas para coleta de dados. In: Métodos e técnicas na pesquisa etnobotânica. Organização Ulisses Paulino Albuquerque; Reinaldo Farias Paiva de Lucena; Luiz Vital Fernandes Cruz da Cunha. Recife: editora Livro Rápido /NUPEEA, 2004. p. 37 62.

ALMEIDA, Lorran. Os sentidos da magia: práticas rituais, sacerdotes e clientes nos terreiros. 2019. Dissertação (Mestrado em Antropologia Social) - Universidade Federal do Rio Grande do Norte, Rio Grande do Norte, 2019. 
BARROS, José Flávio Pessoa de. Ewé Orisà: uso litúrgico e terapêutico dos vegetais nas casas de candomblé jêje-nagô. 2 ed. Rio de Janeiro: Bertrand Brasil, 2003.

BOTELHO, Pedro Freire. O segredo das folhas e os rituais de cura na tradição afrobrasileira. In: VI ENCONTRO DE ESTUDOS MULTIDISCIPLINARES EM

CULTURA (ENECULT). Salvador, Bahia. 2010. Disponível em:

http://www.cult.ufba.br/wordpress/24807.pdf. Acesso em: 15 de fev. 2021.

CONCONE, Maria Helena Villas Bôas. Cura e visão de mundo. In: Pajelanças e religiões africanas na Amazônia. Organização Raymundo Heraldo Maués; Gisela Macambira Villacorta.1 ed. Belém: editora universitária da UFPA. 2008. p. 225- 238,

CORDEIRO, Maria da Conceição da Silva. "Doença de feitiço", ações terapêuticas e os percursos de cura em terreiros de umbanda e candomblé em Macapá-AP. 2016. Tese (Doutorado em Sociologia) - Universidade Federal do Ceará, Ceará, 2016.

DE LUCA, Thaissa Tavernard. Revisitando o tambor das flores. A federação espírita e umbandista dos cultos afro-brasileiros do estado do Pará como guardiã de uma tradição. 2003. Tese (Doutorado em Antropologia) - Universidade Federal de Pernambuco, Pernambuco, 2003.

GOMES, Heloisa Helena Sucupir; DANTAS, Ivan Coelho; CATÃO, Maria Helena Chaves de Vasconcelos. Plantas medicinais: sua utilização nos terreiros de umbanda e candomblé na zona leste da cidade de Campina Grande-PB. Biofar: Revista de Biologia e Farmácia. v. 3, n. 1, p. 110-120. 2008.

IBGE, Censo de 2010. 2010. Disponível em:

https://cidades.ibge.gov.br/brasil/pa/santarem/panorama. Acesso em: 10 março 2021.

IPHAN. Cartografia social dos afrorreligiosos em Belém do Pará - religiões afro brasileiras e ameríndias da Amazônia: afirmando identidades na diversidade. Organização Camila do Valle et al. Rio de Janeiro, Brasília: Casa 8. 2012.

JAGUN, Márcio. Vocabulário Temático do Candomblé. Rio de Janeiro: Litteris, 2017.

LEITÃO-BARBOZA, Myrian Sá; MUNZANZU, Carla Ramos; SOUZA, Izonara Augusta dos Santos; MOURA, Beatriz Martins; PEREIRA, Anderson Lucas da Costa. Confluência de saberes: vivências alimentares e pedagógicas em uma comunidade tradicional de terreiro na Amazônia. In: Coletânea educação para as relações étnico-raciais. vol 1. Organização Cicera Nunes; Jean Gustavo de Oliveira Moraes; Henrique Dias Gomes de Nazareth; Nágila Oliveira dos Santos. Rio de Janeiro: Pachamama editora. 2021.

LIMA, Vivaldo da Costa. Lessé orixá: Nos pés do santo. Salvador: Corrupio, 2010.

L'OMI L'ODÒ, Alexandre. Jurema Sagrada. Webinário Plantas Sagradas de Cura. Convidados Alexandre L'Omi L'Odò e Renato Athias. Canal Kátia Mesel. 2021. Disponível em: https://www.youtube.com/watch?v=FNwKs7KiFF4. Acesso em: 15 abr. 2021.

LODY, Raul. O Povo do santo: religião, história e cultura dos orixás, voduns, inquices e caboclos. São Paulo: WMF Martins Fontes. 2006. 
MOURA, Beatriz Martins. "Aqui a gente tem folha": terreiros de religião de matriz africana como espaços de articulação de saberes. 2017. Tese (Mestrado em Antropologia Social) - Universidade de Brasília, Brasília, 2017.

MUNZANZU, Carla Ramos; LEITÃO-BARBOZA, Myrian Sá. "Interseccionalidade de Saberes": Uma década de vivências nas comunidades tradicionais de Terreiro Amazônidas e as ações de promoção da igualdade racial. In: Estatuto da Igualdade Racial: uma década depois - apontamentos e reflexões. Organização MOLINA, Sandra Cordeiro Molina; Veyzon Campos Muniz. São Paulo: Editora ESA OAB SP Publicações. p. ISBN: 978-6587351-24-7. 2020.

PACHECO, Agenor Sarraf. Religiosidade afro- indígena e natureza na Amazônia. Horizonte, Belo Horizonte, v. 11, n. 30, p. 476-508. 2013.

PEREIRA, Anderson Lucas da Costa. A cabocla Mariana e sua corte Ajuremada: modos de pensar e fazer festa um Terreiro de Umbanda em Santarém. 2017.Tese (Mestrado em Antropologia Social) - Museu Nacional, Universidade Federal do Rio de Janeiro, Rio de Janeiro. 2017.

PIRES, Marcel Viana; ABREU, Priscila Patrocinio; SOARES, Cynthia Silva; SILVA, Delmira da Costa; SOUZA, Breno do Nascimento; MARIANO, Daniela Melo; LUCENA, Emerson Antonio Rocha Melo de. Etnobotânica de terreiros de candomblé nos municípios de Ilhéus e Itabuna, Bahia, Brasil. Revista Brasileira de Biociências. Porto Alegre, v. 7, n.1, p. 3-8. 2009. Disponível em:

http://www.ufrgs.br/seerbio/ojs/index.php/rbb/article/viewFile/1108/839. Acesso em: 10 fev. 2021.

PRANDI, Reginaldo. Mitologia dos Orixás. São Paulo: Companhia das Letras. 2001.

SÁTIRO, Larissa Nascimento; VIEIRA, Jadla Higino; ROCHA, Dougllas Ferreira da. 2019. Uso místico, mágico e medicinal de plantas nos rituais religiosos de candomblé no agreste alagoano. Revista Ouricuri, Juazeiro, Bahia, v. 9, n. 2. p. 45-61. jul./dez., 2019.Disponível em: https://www.revistas.uneb.br/index.php/ouricuri/article/view/5530

Acesso em 10 fev. 2021.

SERRA, Ordep; VELOSO, Eudes; BANDEIRA, Fábio; PACHECO, Leonardo. O mundo das folhas. 1 ed. Salvador: UEFS/UFBA. 2002.

SOUSA JUNIOR, Vilson Caetano. Na palma da minha mão: temas afro-brasileiros e questões contemporâneas. Salvador: UFBA. 2011.

VIEIRA JUNIOR, Itamar. Torto arado. São Paulo: Todavia. 2019.

WEKKER, Gloria. The politics of passion: Women's sexual culture in the AfroSurinamese diaspora. New York: Columbia University Press, 2006. 